\title{
Pitfall in Using Ethyl-2-Cyanoacrylate (Epiglu) for Circumcision-One Institution Experience
}

\section{Chen-Sheng Huang and Chih-Cheng Luo*}

Division of Pediatric Surgery, Department of Surgery, Wan Fang Hospital, Taipei Medical University, Taipei, Taiwan

\begin{abstract}
Background: We herein report our experience for using Ethyl-2-Cyanoacrylate (2-ECA;Epiglu) for skin closure after circumcision.

Methods: From July 2011 to June 2014, 167 patients (mean age 6.3 years) underwent circumcision using 2-ECA for skin closure. The circumcision was performed using a sleeve technique. No stay sutures was done for the first 30 patients and four quadrant stay sutures were applied on the circumferential suture line for the last 147 patients; two thin layers of 2-ECA were applied to the incision and allowed to dry. The duration of skin closure time using 2-ECA and postoperative complications were evaluated.

Results: The skin closure time using 2-ECA average 2.8minutes for the first 30 patients, and less than 2 minutes for the last 147 patients. At a mean follow-up of 16 months (range 5 to 30), four postoperative complications had occurred. Two patients developed bleeding that required a visit to the emergency room by holding pressure. There were three postoperative complications of wound dehiscence following an early postoperative erection. One wound without stay sutures required insertion of the sutures in the emergency room; another two wounds with stay sutures only required a further application of glue. The cosmetic outcomes have been subjectively better than those with standard using interrupted sutures.

Conclusion: A sutureless circumcision closure using 2-ECA is a safe, fast and satisfied cosmesis; but we think the adolescent age group is not recommended, and merit four quadrant stay sutures not only to make the glue application easier also prevent severe wound dehiscence.
\end{abstract}

\section{Keywords: Pitfall; Epiglue; Circumcision}

\section{Introduction}

Traditional circumcision is performed using sutures for reapproximation of skin edges. Although the outcomes with this technique have been excellent, the technique is somewhat time-consuming and has the risk of suture tracks or sinuses [1-3]. The advantages of tissue glue for reapproximation of the skin edges during circumcision have been previously reported [4-6] which include shorter operation time, improved safeness, better cosmesis, and shorter duration of postoperative pain; however, this modality has not gained widespread acceptance and infrequently used in Taiwan. We recently began using tissue glue for skin edge approximation after circumcision and herein report our experience.

\section{Methods}

The present study has been conducted in the Department of Pediatric surgery, Wang-Fang hospital from July 2011 to June 2014, 167 patients (mean age 6.3 years) underwent circumcision using tissue glue for skin closure. The sleeve technique was used for all patients. The outer and inner layers of the prepuce were cut and hemostasis with a unipolar diathermy. Following meticulous hemostasis, no stay sutures was done for the first 30 patients and four quadrant stay sutures were applied on the circumferential line for the last 137 patients. The tissue glue comes in a small bag connecting with small tube; a tip of the tube can be used for precise application of the glue (Figure 1). After application on one side, the tissue glue has to dry for a while before application can occur in the other side. Two thin layers of tissue glue were applied to all the patients. If it spills over on the glans or penile shaft skin accidentally then it has to be wiped of immediately. The cup made by us was used to cover the wound. The skin closure time was noted for each case. The patient were evaluated in the outpatient clinic one to two weeks postoperatively and again at 6 months to asses cosmesis and healing.

\section{Results}

The skin closure time using tissue glue averaged 2.8 minutes for the first 30 patients and 80 seconds for the last 137 patients, reflecting a stay suture and learning curve associated with application. At a mean follow-up of 12 months (range 2 to 16), four postoperative complications had occurred. Two patients developed bleeding that required a visit to the emergency room by holding pressure. There were three patients with aged, 12, 13 and 13.5 years of old developed wound dehiscence following an early postoperative erection. One wound without stay sutures required insertion of the sutures in the emergency room; another two wounds with stay sutures only required a further application of glue. Cosmesis has been very good or excellent and subjectively superior to standard sutured closure with interrupted 5-0 or 6-0 sutures (Figures 2 and 3).

\section{Discussion}

Circumcision is one of the most common surgical procedures [710]. The technique varies from excision without suturing, to Plastibell with ligature, to wound approximation with sutures. The use of tissue glue for wound closure is not new to pediatric surgeon [11-20], and

*Corresponding author: Chih-Cheng Luo, ND, Division of Pediatric Surgery, Department of Surgery, Wan Fang Hospital, N0111,Sec 3, Xinglong RD,Taipei-11696 Taiwan, Tel. 8862 29307930; Fax: 8862 29302448; E-mail: 102145@w.tmu.edu.tw

Received March 18, 2015; Accepted May 13, 2015; Published May 20, 2015

Citation: Huang CS, Luo CC (2015) Pitfall in Using Ethyl-2-Cyanoacrylate (Epiglu) for Circumcision-One Institution Experience. Surgery Curr Res 5: 231. doi:10.4172/2161-1076.1000231

ICopyright: () 2015 Huang CS, et al. This is an open-access article distributed under the terms of the Creative Commons Attribution License, which permits unrestricted use, distribution, and reproduction in any medium, provided the original author and source are credited. 


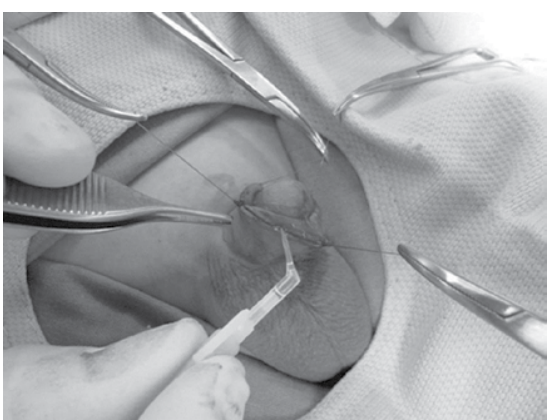

Figure 1: The application of 2-ECA after removal of the foreskin using holding sutures.

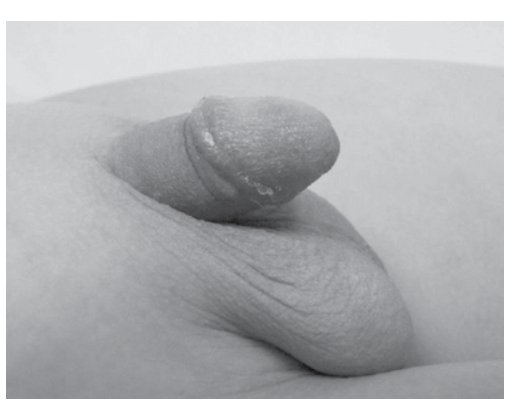

Figure 2: Circumcision closed with 2-ECA at postoperative 2 weeks.

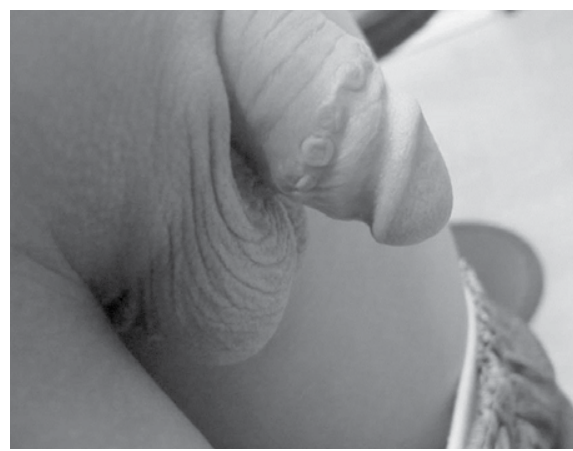

Figure 3: Sinuses after sutured circumcision

particularly the use of cyanoacrylate for circumcision has recently been reported [21-24]. As reported there are advantages that include a better postoperative appearance, a reduced postoperative time and a reduced postoperative pain. We began using 2-ECA for circumcision two years ago after reviewing published data suggesting the above potential benefits.

We firstly noted a significant learning curve associated with application of 2-ECA. Specially, the importance of meticulous hemostasis and four quadrant stay sutures became obvious because bleeding beneath 2-ECA causes an undesirable intraoperative appearance and might compromise the closure.

A dry surface allows for optimal application of 2-ECA. Four quadrant stay sutures causing good skin edges aligned are important which make application of 2-ECA more easier and also can avoid running down of 2-ECA to unwanted adherence to the glans or penile shaft. Therefore, In our study, the average time for the application of 2-ECA can reduce from 2.8 minutes for the first 30 cases to 80 seconds for the last 137 cases.

Secondary, to avoid the other pitfalls of 2-ECA application; in our study, there were a total of five postoperative complications including two patients with bleeding and three cases of postoperative wound dehiscence. Avanogmacr.lu et al have used fibrin glue for hemosatsis after circumcision with hemophilia [25]. In our experience, tissue glue as 2-ECA had no property for local hemostasis, achieving excellent hemostasis is a better way to avoid postoperative bleeding. Some authors [26] recommend that the sutureless circumcision technique be used in boys under the age of 12 due to the increased risk of wound breakdown following penile erection. Three patients with aged, 12, 13 and 13.5 years of old in our study also developed wound dehiscence following an early postoperative erection. Although four quadrant holding sutures can avoid dehiscence being repaired by suture in our cases, we do agree that this technique cannot be done in the adolescent age group.

In conclusion, a suture less circumcision closure using 2-ECA is a safe, and fast method with satisfied cosmesis; but we think the adolescent age group is not recommended, and merit four quadrant stay sutures not only to make the glue application easier also prevent severe wound dehiscence.

\section{References}

1. American Academy of Pediatrics Task Force on Circumcision (1999) Circumcision policy statement. Pediatrics 103: 686-693.

2. Nelson CP (2005) The increasing incidence of newborn circumcision: data from the national wide inpatient sample. J Urol 173: 978-981.

3. Carthcart $P$, Nutall M, van der Meulen J (2006) Trends in pediatric circumcision and its comlications in England between 1997 and 2003. Br J Surg 93: 885-890.

4. Arunachalam P, King PA, Orford J (2003) A prospective comparison of tissue glue versus sutures for circumcision. Pediatr Surg Int 19: 18-19.

5. Subramaniam R, Jacobsen AS (2004) Suture less circumcision: a prospective randomized controlled study. Pediatr Surg Int 20: 783-785.

6. Zafar F, Thompson JN, Pari J (1993) Suture less circumcision. Br J Surg 80 859.

7. Williams N, Kapila L (1993) Complications of circumcision. Br J Surg 80: 1231 1236.

8. Griffiths DM, Atwell JD, Freeman NV (1985) A prospective survey of the indications and morbidity of circumcision in children. Eur Urol 11: 184-187.

9. O'Sullivan DC, Heal MR, Powel CS (1996) Circumcision: how do urologists do it?. Br J Urol ;78: 265-270.

10. Weiss HA, Laeke N, Halperin (2010) Complications of circumcision in male neonats, infants and children: a systemic review. BMC Urol 10: 12.

11. Elmasalme Matbouli SA, Zuberi MS (1995) Use of tissue adhesive in the closure of small incisions and lacerations. J Pediatr Surg 30: 837-838.

12. Burn T, Robinson BS, Smith RJ (1998) A new tissue adhesive for laceration repair in children. J Pediatr 132: 1067-1070.

13. Osmond MH, Quinn JV, Sutcliffe T, Jarmuske M, Klassn TP (1999) A randomized, clinical trial comparing butylcyanoacryl are with octylcyanoacrylate in the management of selected pediatric fascial lacerations. Acad Emerg Med 6: 171-177.

14. Petratos PB, Rucker GB, Soslow RA, Felson D, Poppas DP (2002) Evaluation of octylcyanoacrylate for wound repair of clinical circumcision and human skin incisional healing in a nude rat model. J Urol 167: 677-679.

15. Maw J, Quinn J (1997) Cyanoacrylate tissue adhesives. American J Cosmetic Surg 14: 4.

16. Hasan Z, Gangopadhyay AN, Gupta DK, Srivastava P,Sharma SP (2009) Sutureless skin closure with isoamyl 2-cyanoacrylate in pediatric day-care 
Citation:Huang CS, Luo CC (2015) Pitfall in Using Ethyl-2-Cyanoacrylate (Epiglu) for Circumcision-One Institution Experience. Surgery Curr Res 5: 231. doi: $10.4172 / 2161-1076.1000231$

surgery. Pediatr Surg Int 25: 1123-1125.

17. Qureshi A, Drew PJ, Duthie GS (1997) N-butylcyanoacrylate adhesive for skin closure of abdominal wounds: preliminary results. Ann R Coll Surg Engl 79: 414-415.

18. Ong CCP, Jacobsen AS, Joseph VT (2002) Comparing wound closure using tissue glue verus subcuticular suture for pediatric surgical incisions: a prospective, randomized trial. Pediatr Surg Int 18: 553-555.

19. Quinn JV, Osmond MH, Yurack, Moir PJ (1995) N-2-Butyacrylate: risk of bacterial comtamination with an appraisal of its antimicrobial effects. J Emerg Med 13: 581-585.

20. Osmond MH, Klassen TP, Quinn JV (1995) Economic comparison of a tissue adhesive and suturing in the repair of pediatric facial lacerations. J Pediatr 126: 892-895.
21. Cheng W, Saing H (1997) A prospective randomized study of wound approximation with tissue glue in circumcision in children. J Pediatr Child Health 33: 515-516.

22. Ozkan KU, Gonen M (2005) Wound approximation with tissue glue in circumcision. Int J Urol 12: 374-377.

23. Elemen L, Seyidov TH, Tugay M (2011) The advantage of cyanoacrylate wound closure in circumcision. Pediatr Surg Int 27: 879-883.

24. Fraser ID, Goede AC (2002) Sutureless circumcision. BJU Int 90: 467-468.

25. Avanogmacr.lu A, Celik A, Ulman C, Ozcan C, Kavakli K, et al. (1999) Safer circumcision in patients with hemophilia: the use of fibrin glue for local hemostasis. BJU Int 83: 91-94.

26. Lane V, Vajda, Subramaniam (2010) Pediatric sutureless circumcision: a systemic literature review. Pediatr Surg Int 26: 141-144. 